\title{
A SZELLEM TÖRTÉNÉSZE
}

A két háború közötti korszak hazai szellemi életének egyik legismertebb alakja volt, a magyar filozófiai fejlődésfolyamat fontos kismestereinek egyikeként tarthatjuk számon. A maga korában elismert és népszerü szerző; egyszerre filozófus, könyvtáros, esszéista, publicista. Mint filozófus, a korszak meghatározó bölcseleti irányának, a századelő antipozitivista „újidealizmusát” történet- és kultúrfilozófiává fejlesztö, a két háború közötti szellemtörténet tevékeny népszerüsítője és alapos monográfusa. Mint könyvtáros, elsősorban a hazai bölcseleti múlt dokumentumainak fáradhatatlan számbavevője, fontos szakbibliográfiák összeállítója. Mint eszszéista, a korabeli folyóiratok gyakori szerzője, a magyar nemzeteszme és a magyar nacionalizmus történetének buzgó tanulmányozója. Mint publicista, aggodalommal figyelve a két háború közötti korszak politikájának jobboldali irányváltását, a német orientáció erősödését, a fasiszta veszély növekedését, élénk nemzeti-antifasiszta publikációs tevékenységbe kezd, napilapcikkek sorában foglal állást az értékes nemzeti hagyományok és az európai magyarság eszményei mellett.

Joó Tibor (1901-1945) Kolozsvárott születik, Szegeden tanul, végül Budapesten telepszik le. Az egyetemi-akadémiai hierarchiában nem jut el a legmagasabb posztig: a budapesti egyetemnek nem nyilvános rendes tanára, hanem magántanára csupán. A Nemzeti Múzeum könyvtárának, majd a nemzeti könyvtárnak különböző beosztásokban dolgozó könyvtárosaként azonban jut ideje rá, hogy tudományos és közéleti munkájával foglalkozzék: könyveivel, tanulmányaival és újságcikkeivel a korszak gondolkodástörténetének kiemelkedő alakjává emelkedik. Az ostrom legutolsó napján veszíti az életét, negyvenöt késő telén: túlélve a világégést-átvészelve a bombázásokat és kibírva a nélkülözéseket - éppen följön az óvóhelyröl, amikor egy megkésve felrobbanó légiakna eltévedt repeszdarabja találja el. Alkotóereje teljében van, és tervek sora foglalkoztatja: a történetfilozófus a szellemtörténet történelemfelfogását „történetmetafizikává” szeretné fejleszteni, az antifasiszta publicista a demokratikus újjáépítésből venné ki a részét. Hogy alkotóerejét kibontakoztathassa és terveit megvalósítsa: a könyörtelen sors nem hagy neki rá időt.

Jeles filozófus, rokonszenves patrióta és finom tollú - németes mủveltsége ellenére is inkább a magyar kultúrából annyira fájón hiányzó „franciás” irályú esszéista volt: mindenképpen megérdemli hát, hogy alaposabban megismerjük.

Monográfiájával Filep Tamás Gusztáv most fölnagyítja Joó alakját: aprólékosan utánanyomoz az életútjának, részletesen végigolvassa az életmúvét. Filep az a szerző, aki Joó munkásságának avatott ismerőjeként és lelkes híveként, már eddig is sokat tett a gondolkodó újrafölfedezése érdekében. Előbb sajtó alá rendezte 
Joó „magyar önismereti breviáriumának” új kiadását (Vallomások a magyarságról, 1995), majd Joó születésének centenáriumán összeállította a gondolkodó gyüjteményes kötetét (Történetfilozófia és metafizika, 2001). Ilyen esszékötet korábban nem létezett; tanulmánygyüjtemény nem jelent meg töle sem életében, sem halála után: mostanában reprintben vagy újraszerkesztve újra kiadott kötetei mellett ez lett az első ilyen válogatás. Ez utóbbi kötethez Filep terjedelmes előszót készített, sorra véve benne a gondolkodóról megrajzolt, hagyományos kép elemeit. Eszerint Joó - így az „uralkodónak” és „tudományosnak” tekinthető, közkeletü kép - a szellemtörténeti irányzat legtúlzóbb képviselője volt; a történetfilozófiája nem támaszkodik érdemi történettudományi eredményekre; a nemzeti kérdésnek szentelt könyvei pedig voltaképp csupán Szekfü Gyula életművének popularizálásával szolgálnak.

Ahogy egykori előszava, Filep mostani monográfiája is a hagyományos képnek ezekkel az elemeivel folytatott vitában született. Azt igyekszik tehát bizonyítani, hogy nem: a gondolkodó éppenséggel a szellemtörténeti irány következetes fogalomtisztázójaként tartható számon; történetfilozófiájának anyagát kifejezetten a korabeli történettudomány hiteles eredményei szolgáltatják; az öt egyébként sokra tartó Szekfüvel pedig számos kérdésben vitában áll. Hogy tehát, egyrészt, azonnal több kiadást megérö híres könyve, a Bevezetés a szellemtörténetbe, eminensen ismeretterjesztő célokat maga elé tủzve éppen arra vállalkozik, hogy rendet tegyen a fogalmi zürzavarban: a szellemtörténet szellemfogalmában minuciózusan elkülönítve a tiszta értékrendszert megfogalmazó normatív szellemet, a normatív szellem inspirációit akarattá formáló szubjektív szellemet, illetve a szubjektív szellem tette nyomán kulturális intézményekben tárgyiasuló objektív szellemet. Hogy azután, másrészt, a nemzetfogalomnak és a nacionalizmus problémájának szentelt tanulmányaiban és könyveiben a történetfilozófiai konstrukció éppenséggel a korabeli, harmincas-negyvenes évekbeli történettudomány meghatározó szerzőire támaszkodik, és friss eredményeit építi magába. S hogy végül, harmadrészt, nyilvánvalóan fölhasználja ugyan a korszak szellemtörténete meghatározó történettudósának, Szekfünek munkásságát, ám határozottan distanciát is tart tőle, a maga törekvéseit egyértelmüen nem a történettudomány, hanem a filozófia erőterében elhelyezve: önmagát a Böhm Károly-tanítvány szegedi professzor, Bartók György tanítványaként a Böhm alapította „Erdélyi Iskola” harmadik nemzedékéhez tartozó szerzőként azonosítja.

Joó azok közé a magyar gondolkodók közé tartozik, akik határozottan reflektálnak a filozófiának a hazai kultúrában betöltött csekély szerepére, a magyar filozófia hagyománytalanságára. Teoretikus tevékenységének egyik központi törekvése éppen a magyar filozófiai múlt fölhalmozott hagyatékának számbavétele, kiadása és földolgozása. Mint könyvtáros a nemzeti könyvtár filozófiai kéziratait a teljesség igényével számba vevő szakbibliográfiát készít; mint kéziratgondozó sajtó alá rendezi a maga iskolája alapítójának, Böhm Károlynak az ifjúkori önéletrajzát; mint filozófus számos tanulmányának választja tárgyául a magyar filozófiai múlt alakjait. 
A magyar kultúra antifilozofikus-afilozofikus karakterének és a magyar filozófiai hagyomány gyöngeségének több fontos önálló esszétanulmányt is szentel. Ezekben szembeállítja egymással a létező magyar filozófiai hagyatékot és a nem létező magyar filozófiai hagyományt: annak megértését kísérli meg tehát, hogy az egyébként megszülető hazai bölcseleti teljesítmények miért nem szervülnek a nemzeti kultúra önálló, más kultúrterületekhez hasonló szférájává. Nos, Filep ugrópontját éppen ezek a Joótól átvett megfontolások képezik. A monográfiája elejére emelt bevezető - a magyar filozófia vagy nemzeti filozófia alternatívját fölvillantva - nem egyszerủen megidézi Joó vonatkozó gondolatait: közvetlenül relevánsnak tekintve őket, a maga saját értelmezését közvetlenül azokra is építi. Ez az esszéisztikus eljárás munkáját azonnal megkülönbözteti a tudományos filozófiatörténeti szakmunkáktól. Általában is elmondható, hogy a monográfia nem kapcsolódik az elmúlt jó negyedszázadban intézményesülő magyar filozófiatörténeti kutatásokhoz: mükedvelő munka tehát, szerzőjének a monográfiája hőse iránt érzett lelkes érdeklődéséből és szeretetteljes figyelméből született meg.

Ugyanakkor, másfelől, Filep munkája hibátlan tudományos monográfia. Nem a magyar filozófiatörténeti kutatások áramában született ugyan, mégis a tudományosság kánonjait aggályosan szem előtt tartó, a hősére vonatkozó minden lehetséges tudást magában foglaló munka. A monográfia műfajának régi, a 19. századból származó, a „Leben und Lehre” típusú mintáit követi: a lehető alapossággal föltárni a monográfiahős életének minden megismerhető részletét, lehető teljességigénnyel számba venni munkásságának minden megismerésre érdemes darabját. Nyugodtan kijelenthető, Joóról és művéről még soha nem tudtunk enynyit, mint most, Filep munkájának birtokában. A monográfiából, egyrészt, részletesen kirajzolódik az életpálya, az erdélyi születéssel, a Csongrád megyei családi gyökerekkel, a szentesi gimnáziumi és a szegedi egyetemi évekkel, a Bethlen Gábor Körben kifejtett társadalomreformeri szerepvállalással, a könyvtárosi elörejutás adalékaival, az antifasiszta mozgalomban való részvétellel. A földolgozásból, másrészt, egészében bontakozik ki a teljes életmü, a korai verseskötettől a kései publicisztikákig, a nagy mủvektől az apró újságcikkekig.

„A bibliográfia autopszia útján, elvben a teljesség igényével készült, de ennek az igénynek bizonyára nem tud megfelelni, tehát nem tekintem lezártnak." A monográfia bibliográfiai fejezetének bevezető mondata pontosan jellemzi a vállalkozás egészét. Filep Tamás Gusztáv aggályosan alapos és rokonszenvesen szerény munkát végzett.

(Filep Tamás Gusztáv: Joó Tibor: A szellemtörténet és a magyar nemzeteszme. Budapest: Századvég Kiadó, 2019) 